\title{
Editorial
}

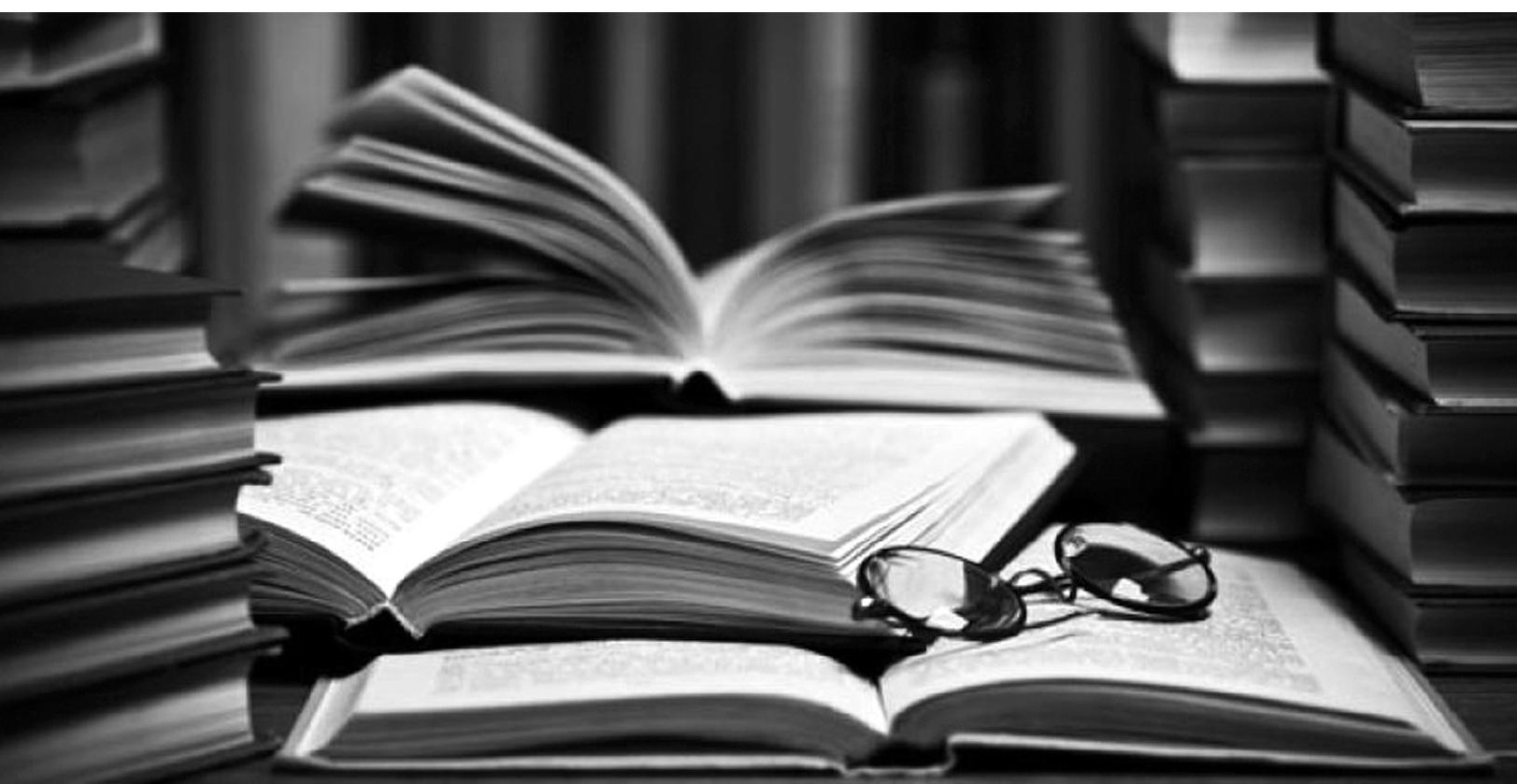





\section{A 100 años de la Constitución de Weimar}

En noviembre de 1919 concluida la Primera Guerra Mundial Alemania necesitaba reestructurarse; la nueva realidad mostraba por una parte, la abdicación del Kaiser Guillermo II que ponía fin al segundo Reich y por otra parte, el Tratado de Versalles que aseguraba la paz pero le imponía disposiciones punitivas para su territorio, milicia y economía, por lo que el escenario era difícil de afrontar bajo las mismas instituciones.

Realidad que fue bien interpretada por la propia sociedad Alemana, pues entendieron que era necesario un cambio desde la propia concepción de sus instituciones y se permitieron dar un giro trascendental en el régimen establecido hasta entonces, dando paso a la República Federal Alemana.

Recordemos que la Primera Guerra Mundial dejó a Alemania una perdida del 13\% del territorio europeo, -69,939 km2- y un décimo de su población, -entre 6 y 7 millones de personas- provocando con ello una enorme conmoción política y social.

Se requería un profundo cambio, una auténtica transformación y ellos decidieron que fuera mediante sus propias instituciones, no partieron de cero, por el contrario dieron un gran paso adelante, evolucionando su statu quo, dando inicio a lo que sería el germen de una nueva sociedad que nace con gran legitimidad.

Se logró escuchar a todas las voces internas y unificarlas para crear una nueva realidad social, la tendencia socialdemócrata imperó en la transformación del Estado Alemán, y la nueva Constitución de Weimar dibujo un nuevo contexto de paz, unidad, democracia y solidaridad por el otro. El texto tomado del preámbulo de la constitución de Weimar reza así:

La nación alemana, acorde en sus diversas ramas y animada de la voluntad de renovar y consolidar su Reich -Imperio- en nombre de la libertad y de la justicia, servir a la paz interior y exterior y fomentar el progreso social, se ha dado esta Constitución". 
Silvia Patricia López González

Libertad, justicia, paz y progreso social fueron los pilares de un nuevo modelo democrático, que a la luz de la historia puede considerarse un sistema político progresista que sentó las bases del Estado de bienestar, tan anhelado hoy en día en todos los países democráticos.

Los derechos humanos llamados de segunda generación, que son los derechos económicos, sociales y culturales aparecen por primera vez protegidos en esta Constitución, sumándose a los de primera generación, que tienen que ver con la protección de los derechos civiles y políticos.

En definitiva todos ellos buscan proteger y otorgar las mejores condiciones de vida para los ciudadanos primando en todo caso la dignidad de la persona.

La Constitución de Weimar, al igual que la Constitución Mexicana dan inicio con el constitucionalismo social, en el cual, no solo se determinan limites al poder del Estado, sino que éste, debe ejecutar determinadas políticas sociales que garanticen y aseguren el bienestar de todos los ciudadanos.

Políticas públicas que garanticen el derecho a la salud, a la educación, a el trabajo y en general, a todos los derechos que fomenten el pleno desarrollo del ciudadano.

La transformación del Estado Liberal clásico al modelo Constitucional del Estado Social conlleva no solo una transformación en el ámbito político sino una transformación en el ámbito jurídico, que implica una forma diferente de comprender y administrar la justicia.

En un Estado Social de Derecho la justicia social juega un papel muy importante, ya que el Estado adquiere la obligación Constitucional de proveer mediante los valores de libertad, igualdad y paz el logro del pleno desarrollo de los ciudadanos, lo cual queda muy lejos de tan sólo conformar un catálogo de leyes.

Como lo expresó el jurista Aleman Hermann Heller el cual participó durante la República de Weimar: El poder del Estado es siempre legal, en tanto se fundamenta en la legitimidad, -esto es- sin la apelación de preceptos éticos la mayoría de las normas constitucionales podrían ser de imposible aplicación.

Verano 2019

Dra. Silvia Patricia López González Director-Editora 